\title{
'It Sends a Cold Shiver down My Spine' Ghostly Interruptions to Strategy Implementation
}

Pors, Justine Grønbæk

Document Version

Accepted author manuscript

Published in:

Organization Studies

DOI:

10.1177/0170840616655495

Publication date:

2016

License

Unspecified

Citation for published version (APA):

Pors, J. G. (2016). 'It Sends a Cold Shiver down My Spine': Ghostly Interruptions to Strategy Implementation. Organization Studies, 37(11), 1641-1659. https://doi.org/10.1177/0170840616655495

Link to publication in CBS Research Portal

\section{General rights}

Copyright and moral rights for the publications made accessible in the public portal are retained by the authors and/or other copyright owners and it is a condition of accessing publications that users recognise and abide by the legal requirements associated with these rights.

Take down policy

If you believe that this document breaches copyright please contact us (research.lib@cbs.dk) providing details, and we will remove access to the work immediately and investigate your claim. 


\section{'It Sends a Cold Shiver Down My Spine': Ghostly Interruptions to Strategy Implementation Justine Grenbæk Pors}

Journal article (Post print version)

Cite: 'It Sends a Cold Shiver Down My Spine' : Ghostly Interruptions to Strategy Implementation. / Pors, Justine Granbæk. In: Organization Studies, 29.07.२016.

Dol: http://dx.doi.org/10.1177/0170840616655495

Uploaded to Research@CBS: September २016 


\title{
'It sends a cold shiver down my spine' \\ Ghostly interruptions to strategy implementation
}

\section{Justine Grønbæk Pors}

Department of Management, Politics and Philosophy, Copenhagen Business School.

\begin{abstract}
A later version of this paper will be published in Organization Studies. DOI: $10.1177 / 0170840616655495$
\end{abstract}

\begin{abstract}
This paper offers new theoretical and empirical understanding of interruptions to strategy implementation by drawing attention to their ghostly nature.

The paper proposes a theoretical framework for thinking about the ghostly by combining Freud's concept of the uncanny with theorizing in cultural geography on collapses of linear time as well as with Avery Gordon's sociological work on ghostly matters.

Empirically, the paper examines the ghostly nature of strategy interruptions through a detailed analysis of conversations between middle managers at a strategy seminar in a Danish local government. I portray the uncanny moments where the familiar account of organizational purposes is not so self-evident anymore, but all of a sudden appears rather disturbing. I show how middle managers envision other, darker futures and express the feeling that something else, something different from before, must be done, although they cannot say exactly what.

Going beyond previous accounts of strategy interruption e.g. as deliberate resistance of middle managers, the paper contributes with new insight into the moments where the neat ordering of organizational realities performed by corporate strategies break down and middle managers come into contact with the broader social and political stakes of their work.
\end{abstract}

\section{Introduction}

We are in the assembly hall of a large Danish primary school. The hall is not full of children, but of the middle managers of the school system seated around circular tables. They are summoned to one of the monthly strategy seminars arranged by the top management in the local government in order to discuss the implementation of a new comprehensive assessment system. The sounds of many voices fill the room and it is impossible not to notice the enthusiasm of the middle managers. Around the tables, 
managers are eager to display their dedication to the new system and to voice their regrets that some staff members have not yet understood the importance of change. At one point, at one table, one manager pauses and then, out of context, states: 'Actually, when I think about all the adverse consequences this will have for our children in the future, it sends a cold shiver down my spine.'

This study begins with that sentence: 'it sends a cold shiver down my spine.' The statement conveys such a clear and unmistakable corporeal experience, yet it is not easily interpreted. There is no obvious way of explaining why the manager felt a shiver down her spine at that point in the larger change process or at that particular point in the conversation. In the familiar setting of a recurring strategy seminar where managers were keen to demonstrate their capability to transform individual subunits, all of a sudden, one manager glimpsed into another, more gloomy, future than the one offered to her by the glossy strategy documents of an improved and better performing primary school.

This paper develops a theoretical framework apt to explore the moments in which organisational actors, if only fleetingly, come to wonder about the complexities of their strategic effort and the larger social and political stakes involved. I suggest a theory of the ghostly and put it to work in an empirical analysis of how one particular statement ('it sends a cold shiver down my spine') at a habitual strategy seminar sat in motion a trail of reflections capable of challenging the present and opening to lost futures (Blackman, 2015, p. 28).

From the outset, I want to stress that the concept of the ghostly I suggest does not refer to the well-known and smoothly shaped narrative of a person returning from the past to haunt the present until the injustice he was subject to can be set right and the dead laid to rest. In Frederic Jameson's (1999, p. 39) words, what the ghostly suggests is not that the ghost exists, but that 'the living present is scarcely as self-sufficient as it claims to be; that we would do well not to count on its density and solidity.' Thinking about the ghostly is about noticing how there is a lot more going on in the organizational everyday than what is suggested by the linear orderings of time produced by strategy narratives. It is about being attentive to the ways in which, once in a while, the different pasts and the alternative futures that corporate strategies manage to 'unsee', forget or derecognize come to resurface. Paying attention to the ghostly, I 
argue, is one way of tuning into the 'immense forces of atmosphere' (Benjamin, 1978, p. 182) concealed in everyday conversations to discover the tangled ways middle managers sense and intuit the complex consequences of organisational change.

A few contributions in this journal have already brought attention to the uncanny or even ghostly qualities inherent in organization and management (Beyes \& Steyaert, 2013; Gabriel, 2012; see also De Cock, O’Doherty \& Rehn, 2013; Muhr \& Azad, 2013). Particularly Orr's (2014) study of how local government chief executives encounter and live with ghosts has demonstrated, not only that we find ghostly presences in mundane organizational settings, but also that analytical curiosity about ghostly workings can enrich our understanding of organizational change and transformation of organizational traditions. However, when compared to other social sciences, it seems, organisation studies has yet to benefit from a burgeoning theorizing of the ghostly (e.g. McCormack, 2010; Gordon, 2008; Hetherington, 2004; Maddern, 2008). In cultural studies, geography and sociology, an analytical interest in the ghostly has produced apposite insights into what urban space is and how it affects us (Pile, 2005; Till, 2005; Edensor, 2008, 2001), what it means to live in a dictatorship (Gordon, 2008), how colonial pasts shape present day political practices (Coddington, 2011), or how war and violence linger in humans and culture across generations (Cho, 2008).

To demonstrate how a study of the ghostly can form a contribution to wellestablished disciplines within the fields of organization and management, I relate my findings to debates in middle management studies. In the literature, the role of middle management is described as strategy implementation (Raes, Heijltjes, Glunk \& Roe, 2011; Floyd \& Wooldridge, 1992; Johnson \& Frohman, 1989). Hitherto, studies on disruptions to implementation have concentrated on cases in which middle managers deliberately resist and counter corporate strategies because they have a rational selfinterest in doing so (Meyer, 2006; Ketokivi \& Castañer, 2004; Guth \& MacMillan, 1986; Dutton \& Ashford, 1993). When studies have sought to understand more elusive and emotional aspects of strategy interruption, they have focused on how middle managers struggle to make sense of their role and create identity in spite of competing pressures from above and below in the organizational hierarchy (Harding, Lee \& Ford, 2014; Sims, 2003; Thomas \& Linstead, 2002). Going beyond rationalistic accounts as well as a focus on identity struggle, this paper is concerned with those moments where 
neat capturing and ordering of the organizational reality as linear progress collapse, and middle managers glimpse into other, gloomier futures than the ones offered to them by corporate strategies. With a point of departure in the statement, 'It sends a cold shiver down my spine,' I am particularly interested in how such moments may bring those who experience them into contact with broader social and political stakes of their work.

In the following, I will first briefly review the literature on middle management and strategy implementation. Second, drawing on seminal work on the ghostly in social theory, I develop a theoretical framework for thinking about the ghostly in the context of management studies. Third, I present my methodology and describe how a study of middle management in the Danish Education system became a study of the ghostly. Fourth, I introduce the empirical setting of the study and analyse conversations between middle managers at the seminar in which a ghostly moment emerged and middle managers glimpsed into other futures than the one depicted by the corporate strategy. Fifth, I discuss my findings in relation to the middle management literature. Finally, I offer a conclusion.

\section{Middle management as strategy implementation}

Traditionally, the literature portrays middle managers as 'linking pins' responsible for aligning operations in subunits with corporate goals and visions (Raes, Heijltjes, Glunk \& Roe, 2011; Nutt, 1987; Hrebiniak \& Joyce, 1984; Nonaka \& MacMillan, 1986).

Several scholars have critically noted that the corporate strategies middle managers are meant to implement are often based on a conception of organizational change as a linear sequence of events moving the organization from an actual to a desired state (Chia, 1999; Tsoukas \& Chia, 2002; Carter, Clegg \& Kornberger, 2008). This linear conception of change is supported by a belief in the possibility of causal relations between particular, deliberate managerial acts and specific outcomes (Chia \& McKay, 2007). Through the idea that certain actions will produce certain effects a singular organizational path from the past, through the present and towards a particular desired future can be assembled. Moreover, as scholars have argued, strategy narratives often implicitly assume that the organizational reality, i.e. its past, present and future, can be linguistically captured and accurately represented through established categories, 
concepts and representations (Chia \& Holt, 2009, p. 23). The promise of corporate strategies is that they can eliminate uncertainties and control the future through welldefined visions and unambiguous priorities (Clegg, Carter \& Kornberger, 2004). Thus, corporate strategies are designed to offer middle managers a social space in which uncertainties are handled and contained through the ordering and sequencing of organizational time, the clear formulations of goals and the actions necessary to achieve them. What remains unexplored, however, is the particular quality of moments where such social spaces and their ways of ordering reality break down. This paper seeks new understanding of those intriguing instants where the capturing of organizational realities in neat, linear sequences collapses and middle managers begin to doubt the causal relationships portrayed by corporate strategies between certain actions in the present and a particular glossy future.

In the existing literature on middle management, disruptions to the linearity of strategy implementation are often conceived of as middle managers active resistance to corporate decisions (Bower, 1970; Ketokivi \& Castañer, 2004; McCabe, 2011). Research has tended to concentrate on cases in which middle managers have an obvious, rational self-interest in resisting, for example because corporate strategies threaten their position in the organizational hierarchy or the existence of their subunits (Meier, 2006; Guth \& MacMillan, 1986). Thus, resistance to corporate strategies is portrayed as deliberate, well organized and driven by individuals, who demonstrate strong and skilful leadership (Zoller \& Fairhust, 2007; Courpasson, Dany \& Clegg et al., 2012).

Some studies have depicted less deliberate forms of disruption to strategy implementation. Regnér (2003) relates interruption to geographical distance in his study of how strategic activities differ between the centre and periphery of large companies, reflecting different locations and social embeddedness. Pointing to the significance of social negotiations of meaning, Balogun and Johnson (2004, 2005) have explained interruptions as a difference in sensemaking between top and middle management (see also Mantere, 2013; Mantere \& Vaara, 2008). Moreover, a set of studies has sought to understand what happens when middle managers come to 'loose the plot' (Thomas \& Linstead, 2002) offered to them by corporate strategies. However, such studies have focused on the difficulties of being a middle manager (e.g. Harding et al., 2014;) with 
the explicit aim of showing the constant struggle of middle managers to create a coherent identity and a sense of 'self' in spite of competing pressures (Linstead \& Thomas, 2002). This means that strategy disruption is related to how middle managers become de-energized and despondent due to feelings of loneliness and vulnerability (Sims, 2003).

Thus, as yet, interruptions to strategy implementation have been described as deliberate resistance, as differences in sensemaking between top and middle management or been related to the emotional stress that comes with the role as a middle manager. Beginning in the experience of a cold shiver down a spine in the middle of a strategy seminar, this paper offers another account. A cold shiver is not deliberate resistance. Nor is it accurately captured as misinterpretation of strategic intents or differences in sensemaking as a result of different geographical and social settings. It is something subtler than that. It is a moment where a familiar account of an organizational reality is not so self-evident anymore, but all of a sudden appears rather disturbing. In the following, I develop a theoretical framework apt to explore the quality of such moments.

\section{Theorizing the ghostly}

'It sends a cold shiver down my spine.' What is the quality of such an experience? A breath of cold wind in an otherwise warm and cosy atmosphere? A swift quiver of a calm body? A sudden and fleeting shift or reorientation of how we normally perceive and make sense of things? Perhaps also a sense that something more is unfolding in front of us than what we normally perceive? There is a sense of a relation between a safe dwelling in a well-known and comfortable setting and an, if indeterminate, disturbance of this setting. Such wonderings lead us to Freud's essay on the uncanny.

In this section, I begin in Freud's writings on the uncanny and add to this theorizing within contemporary geography on collapses of linear time. I also draw on Avery Gordon's $(2008,2011)$ understanding of the ghostly as a state when something different from before feels like it must be done.

\section{Uncanny moments}


For Freud, an uncanny experience is qualitatively different from the fear arising from an encounter with the unfamiliar and foreign. Likewise, it is more than a simple sense of not belonging. 'Something has to be added' for an experience to be uncanny, Freud (2003, p. 125) stresses.

Reading Freud's essay on the uncanny is a staggering experience of repeatedly being offered a definition of the uncanny only to lose it again as Freud proceeds to new explorations, arriving at new definitions of what the uncanny might mean. As Hélène Cixous (1976) has eloquently argued, what is so fascinating about the essay is that the form and structure of the text, constantly undo what the text seeks to establish. It is as if the text, or its author, is haunted by a shadow of doubt and hesitation (Cixous, 1976, p. 526). Just as the reader thinks she is following a particular demonstration, she senses that the surface is cracking: '[W]hat is brought together is quickly undone; what asserts itself becomes suspected.' (Cixous, 1976, p. 526). The result is that indefiniteness and hesitation becomes part and parcel of the concept. An uncanny experience is a moment where you cannot quite decide what to think. A moment where you hesitate and begin to doubt the reality unfolding in front of you.

As Beyes and Steyaert (2013) have laid out in this journal, among other things, Freud's essay consists of a lexicographical exploration tracing the origin and the historical development of the concept of the uncanny. What Freud finds is that although the homely initially meant familiar, friendly and a place free of ghostly influences, over time, it increasingly became ambivalent, until it merged with its antonym, unhomely ${ }^{1}$ (Freud, 2003, p. 134). Through this etymological route, the uncanny came to describe the confusing, yet itchy feeling that an encountered foreign world is vaguely familiar: that the foreign has a, however cryptic, route back to the familiar (Freud, 2003, p. 148). Freud (2003, p. 124) arrives at a description of the uncanny as 'that species of the frightening that goes back to what was once well known and had long been familiar.' The uncanny comes to denote a sneaky feeling that boundaries between familiar and unfamiliar, homely and unhomely are more porous, leaky and precarious than normally assumed.

This particular quality of uncanny experiences is a first step towards the conception of the ghostly I am trying to develop. I want to stress the performativity of uncanny experiences; what uncanny moments might do to the people who experience 
them. The uncanny is an experience that reminds us that our safe dwellings in familiar and homely spaces are rarely unambiguously that. As such, they are full of uneasiness arising from the way in which a familiar narrative all of a sudden turns on its users and become defamiliarised, derealised, casting doubt on the familiar narrative (Vidler, 1999, p. 7). Perhaps stretching Freud's account slightly, I understand uncanny moments as moments that make people wonder about the self-description of the familiar as familiar. The uncanny is a sneaky feeling that something in the ways of working of familiar narratives is not available to us, and the dawning that the familiar narrative might be an animate force in making counter narratives appear foreign or even silence them. The uncanny performs as a vague reminder that work is being done to maintain something as familiar, necessary and uncontested. Perhaps uncanny moments even make us consider how we, with our own daily practices, are parts of the on-going work to allow familiar narratives to sustain their hegemony as familiar.

In the following, I add theorizing on the collapse of linear time in order to attune the theoretical sensitivity towards how the familiarity that uncanny moments may make us question is the familiar orderings of time utilized by organizations to structure and align the strategic efforts of their members (e.g. what ideas about the future to work towards, what depictions of the past to leave behind).

\section{Collapse of linear orderings of time}

In contemporary geography, much work has been done to show how modern, linear imperatives to swiftly transform and renew are only partial in their attempts to remove the past (Edensor, 2008, 2001; Degen \& Hetherington, 2001). Through studies of urban space, underground sewers, commuting routes, industrial ruins and metro lines, a number of studies have explored how, in spite of attempts to renovate and improve, social and material spaces are still crowded with lingering remnants of former ways of life, outdated working routines, long gone cultural fashions, failed city planning and materiality in different stages of decay (Hetherington, 2004; Maddern, 2008; Pile, 2005; Till, 2005; Gandy, 1999). The rubbished, forgotten and neglected do not simply disappear, but immerse present apparent orders, leaving them, as de Certeau (1984, p. 107) puts it, 'punched and torn open by ellipses, drifts and leaks of meaning.' 
The ghostly is something that messes with the common, but here, unhelpful narrative structuring of the ghost as a return of the past. I suggest that the ghostly is moments in which, if only fleetingly, a familiar linear ordering of time collapses. These are moments where it becomes possible to catch a glimpse of what we can call, following Wright (in Luckhurst 2013, p. 81), broken fragments of time. Such broken fragments are not necessarily repressed, traumatic pasts, but may also be lost, forgotten or silenced futures. Degen and Hetherington (2001, p. 4) have suggested that building sites and new developments are just as likely to be haunted as cemeteries or abandoned buildings, 'not just because of what they rub out but because within their expressions of novelty, pride, social engineering we find the tragic, ghostly voice of the future evoking the inevitable failure of such spatial dreamings'. The ghostly is not simply a moment that presents you with a clear vision of something from the past that was excluded and repressed. It is not entities from the past, compartmentalized and ready to be claimed. The ghostly is much too unruly to simply satiate such narratives (Edensor, 2008; Holloway \& Kneale, 2008). When I propose that ghostly experiences allow organizational actors to catch a glimpse of other orderings of time, it is in an excessive, overdetermined fashion, where it is not decipherable if the encountered heterogeneous elements belong to the past, present or future. The ghostly disrupt linear orderings of time, but it does not in any straightforward manner propose other orderings of time. As Pile (2005, p. 162-163) has suggested, the ghostly is not coherent. It can mean many things at once: 'just like an element in a dream, the figure of the ghost is overdetermined - pointing in many different directions at once.' The ghostly is indeterminate entanglements of time: 'Endings that are not over' (Gordon, 2008, p. 139) and futures never begun. There is always an excess to the ghostly.

I have arrived at an understanding of the ghostly as an uncanny moment where the linearity of corporate strategies collapses and an excess of other possible orderings of time open up. In the following, I add Gordon's $(2008,2011)$ work on the ghostly as a transformative recognizing of broader social and political stakes.

\section{A something-to-be-done}

In her seminal work on 'Ghostly matters', Gordon describes the ghostly as very different from a traumatic experience in that it produces a longing for counteraction. 
Meeting the ghostly, Gordon (2008, p. 8) argues, draws us 'always a bit magically, into the structure of feeling of a reality we come to experience, not as cold knowledge, but as transformative recognition.' For Gordon, the ghostly is what makes people begin to notice the shadows of contemporary political power. She coins this experience as a vague feeling of a 'something-to-be-done' and explains the ghostly as a 'socio-politicalpsychological state when something else, or something different from before, feels like it must be done.' (Gordon, 2011, p. 3) I want to stress that this does not mean that people who have such experiences know exactly what to do, how and when. Neither does it mean that people actually act out the need for action they feel. The ghostly is

more like a question than a coherent vision. It is unresolved tension and more like something waiting to happen, than an actual event. Ghostly moments are experiences that bring organizational actors into contact with doubts and ambiguous feelings towards the change they are meant to produce, but in an indeterminate and hesitant way. It is a vaguely felt urgency, meanwhile, we carry on with whatever business we were doing in the first place.

Thus, drawing on Gordon's work, I add to the theoretical framework that the ghostly is an encounter with concerns beyond implementation of corporate strategies. The ghostly is an experience of coming into contact with the broader social and political stakes of one's daily efforts.

\section{The ghostly}

I have arrived at a framework for thinking about the ghostly as uncanny moments where the linearity of corporate strategies collapses and an excess of other possible orderings of time open up, allowing organizational actors to come into contact with the broader social and political stakes of their work.

This framework, I argue, makes it possible to move the understanding of interruption to strategy implementation beyond the rationalistic accounts and the focus on individual identity struggles of the existing research. It is apt to explore those moments in the everyday life of middle managers were they experience a collapse of well-known corporate narratives and sense the broader social and political implications of their strategic efforts. 


\section{Methodology}

The empirical data that I present was part of an exploration of the management practices in the Danish education system with a point of departure in ethnographic fieldwork in two local governments. Through the use of different methods such as interviews, nonparticipant observations, document studies and shadowing over a period of 17 months, my aim was to provide detailed accounts of various aspects of the management of Danish schools (Ybema, Yanow, Wels \& Kamsteeg, 2009).

Table 1. The studied local governments.

\begin{tabular}{|l|l|l|}
\hline & Local Government 1 & Local government 2 \\
\hline Inhabitants & 191.600 & 60.000 \\
\hline Children in primary schools & 17.500 & 6900 \\
\hline Number of schools & $\begin{array}{l}40 \text { (size varies from 150-780 } \\
\text { pupils) }\end{array}$ & $\begin{array}{l}17 \text { (size varies from 125-712 } \\
\text { pupils) }\end{array}$ \\
\hline $\begin{array}{l}\text { Average number of staff members } \\
\text { per subunit }\end{array}$ & 47 (part time staff included) & 49 (part time staff included) \\
\hline
\end{tabular}

The middle managers in this study are managers of individual schools whose staff members include teachers, pedagogues and technical and administrative support. From the beginning, a central focus was relations and conflicts between the strategic and managerial logics of the top management and the everyday work at the schools. The 'site' that I was interested in was neither the municipal administration, nor the schools, but the borderlands between them. Such a borderland did not 'exist' as a place I could go, but emerged at different locations (meeting rooms at the town hall, assembly halls at schools, a conference hotel at the coast 50 kilometres away etc.) with different events such as strategy days, information meetings, contract- and assessment conversations etc. Drawing on Czarniawska's $(2008,2007)$ coining of shadowing as fieldwork on the move, I began by shadowing initial informants. As Czarniawska (2008, p. 10-11) has argued, shadowing enables one to move across domains and physical locations and thus to follow the connections and tensions between different parts and logics of an organization. I found events in which all the middle managers were brought together to be informed about and discuss strategic change to be particularly rich sources of data because they were often designed as a forum for taking up, sharing and discussing the difficulties of strategy implementation. In collaboration with an initial informant, I 
designed the fieldwork so as to focus on situations where middle managers were summoned, leading to 27 days of observing and interviewing. All citations that appear in this article have been recorded on tape and transcribed.

Table 2. Overview of observations and interviews.

\begin{tabular}{|l|l|l|}
\hline Event & Amount & Duration \\
\hline $\begin{array}{l}\text { Performance review conversations between top-management and } \\
\text { individual middle managers }\end{array}$ & 4 & 2 hours \\
\hline $\begin{array}{l}\text { Performance review meetings between top-management, middle } \\
\text { managers and their team of deputy managers }\end{array}$ & 4 & $4-5$ hours \\
\hline Strategy seminars in the local government & 6 & Half-full day \\
\hline Strategy seminars at a conference hotel & 2 & Two full days \\
\hline Information meetings & 4 & 2 hours \\
\hline Interviews with middle managers & 8 & $1-2$ hours \\
\hline Interviews with top management & 4 & $1-2$ hours \\
\hline
\end{tabular}

\section{Towards the ghostly}

After having written about some of the themes I initially set out to study such as contradictions in contemporary management and the pressure on public middle managers to renew public services, I kept feeling that there was something more to say, something more to be curious about. The statement, 'It sends a cold shiver down my spine,' kept surfacing in my attempts to make sense of this feeling. The statement became what Blackman (2015) calls an 'attractor', that is, a statement that sets in motion a new analytical trail. It seemed to invite me to look for other theoretical resources than the ones with which I had begun the study. Blackman proposes that a hauntological methodology begins with a particular attention to the 'liveliness of a statement' in her words 'the capacity of a statement to perform a series of displaced, submerged, disqualified, or disavowed relations that might undo the present and open to lost futures.' (Blackman, 2015, p. 28) I began to explore what it would mean for this study to see the statement as 'lively' in the same sense and looked for theoretical resources that could unfold how the statement was capable of challenging customary capturing and ordering of the organizational reality in a linear narrative, allowing other thoughts and concerns to surface. 
This means that the study was conducted with a dynamic relationship between theoretical sources and empirical material. The empirical material, and particularly that one statement, presented me with certain riddles that set new theoretical interests on the move, which then again allowed me to return to the data with new resources for trying to understand what was going on (Alvesson \& Sköldberg, 2000, p. 252).

In a vast literature on the ghostly across social theory and philosophy, I found Freud's essay on the uncanny a rich place to begin to explore this experience when a familiar social space, all of a sudden feels strange and disturbing. I added to this theorizing in contemporary geography on the collapse of linear time as well as Gordon's work on ghostly matters, firstly, because these ideas seemed apt to unfold what occurs in the specific moments in the data that I was interested in. Second, these theoretical resources address what the existing literature on strategy interruption leaves out, namely the particular quality of moments where the linearity of a strategy narrative collapses and how such moments may trigger concerns for adverse consequences of everyday work. What links the three theoretical elements is that they all dismiss a simple idea of the ghost as the return of something that should be dead, and stress the excess, the indeterminacy and the hesitation of ghostly moments.

I do not claim that my empirical data speaks directly and only to this framework of the ghostly. Nor do I propose that a theory of the ghostly is the one best way to explain what is at stake in the empirical material. Rather, I have allowed the empirical material to develop and reshape theoretical ideas and let the theoretical resources inspire considerations of different meanings of the empirical material (Alvesson \& Sköldberg, 2000, p. 249-250).

\section{What does it mean to approach the data as ghostly moments?}

The ambition to explore the ghostly has meant that in the large data set, I insistently zoom in on tensions between familiar orderings of time and statements, experiences and occurrences that mess with such orderings. This is an approach, which emphasises the significance of rich moments of felt experience (Symon \& Cassell, 2012) and where the researcher makes use of her ability to be surprised by what she sees or hears, even if it is only a minor and fleeting occurrence (Kociatkiewicz \& Kostera, 1999). 
In what follows below, I first present the empirical setting in some detail. I show how the executive strategy meant to transform schools into more efficiently managed, better performing and self-assessing organisations is crafted into a linear story-line with particular representations of past, present and future (Boje, 1991, p. 106). Thereafter, I present and analyse three small conversational turns from one strategy seminar. The first is chosen to show how middle managers confirm the familiar narrative. The next two scenes are staged with the purpose of zooming in on those minor moments where the grand corporate strategy narratives are interrupted.

The interest in the ghostly directs my attention to minor changes in register and to fleeting collapses of customary narratives. It makes me focus on comments that I might otherwise have excluded from the analysis either because they seemed unimportant in the sense that they were foreign to the customary ways of representing the organisational reality, or because these statements were not easily interpreted as they did not convey a clear, elaborated and coherent counter-narrative. As the analysis concentrates on openings with yet unspecified meaning rather than outcomes, results and endings, what is thereby lost is the ability to, through a longitudinal analysis, follow how these uncanny moments do or do not develop into other forms of resistance or compliance.

\section{Empirical setting and its familiar strategy narrative}

There is a ubiquitous sense of great change everywhere I go during my fieldwork in the two local governments. The story that is repeated to me over and over is that for many years the area of education was left to itself outside critical managerial attention, but that now the situation is completely altered and schools have become the object of what some informants call an avalanche of reforms and change initiatives. Informants explain the situation by referring to media commentators and educational experts' talk about 'PISA-chocks', thus referring to the results of international comparisons in which Danish school children are not performing as well as expected. The chief executives I interview all agree that the current strategic challenges to be tackled are the ones initially coined in a now almost legendary OECD report (2004), namely a lack of efficient management and of a coherent and systematic assessment culture. As a result, 
middle managers at the individual schools are presently confronted with a host of new initiatives. As an informant, a chief executive, puts it:

We have to do this and that, but then another policy maker says, yes but also this and that. We can't do it all. We don't have time to carefully design our initiatives and processes. A new thing knocks on the door. New chief executives, new politicians. An overexcited minister. We also get good ideas in this administration. There are far too many people who want to set the agenda.

From many levels, middle managers are confronted with a pressure to implement new initiatives: New national legislation including compulsory testing of pupils at different stages and yearly quality reviews of schools; initiatives designed to produce change on a cultural level, working with the willingness of teacher collectives to accept new assessment procedures (Local Government, Denmark (LGDK), 2005, 2009); intense management development projects with yearly performance reviews; and finally, in the local government where the strategy seminar with which I begun took place, the implementation of a new large and comprehensive assessment system.

Across the many different strategy documents and initiatives, I find the same narrative about the history and the future of schools. The past is portrayed as a time in which teachers were not obliged to communicate and document their efforts, choices and results. Teachers' practices and methods were not evidence-based, teachers' collaboration was unprofessional and coincidental and the organization was ruled by the belief that the choice of teaching methods was an individual and subjective matter (e.g. LGDK 2005). The past is depicted as one in which teachers could work behind a closed door to their classroom without interference because the culture and tradition demanded that managers did not intervene (LGDK, 2005, p. 13-16). Moreover, the past is described as a time in which deliberate strategic change was difficult due to a strong influence on decision making of the teacher union.

Simultaneously, the strategy documents depict a future in which strong middle managers ensure improved and better performing schools (LGDK, 2010a, p. 6, 2009, p. 9; Danish Ministry of Education, 2007; Danish Institute of Evaluation, 2006). This is a future in which middle managers actively demonstrate responsibility and accountability 
in relation to visions and strategies of local governments (LGDK, 2005, p. 2, 2010b, 2008) and are not afraid to use the management competence they have been given. Thus, in the present, middle managers are under pressure to transform themselves and the way they practice their role as managers. The familiar narrative goes that until now, school managers have interpreted their role as head teachers, intimately part of the teacher collective, but that now, they need to step into a new role as managers in the larger organization (LGDK, 2005).

Across strategy documents the organizational reality is captured and crafted into a narrative with particular versions of the past, the desired future and the present challenges. Through descriptions of the past as inadequate, present efforts to improve and a future of better performance, a need for organizational change in the form of a sequence of events leading from the past, over the present to the future is constructed. Moreover, the strategy narrative installs a set of causal relations between certain actions and better results (for example between more management and more aligned teaching practices or between more assessments and better performing pupils), thereby producing a linearity from certain actions in the present to an improved future (see Chia \& McKay, 2007). This particular way of representing the organizational reality means that other possible pasts, e.g. rich pedagogical values and traditions, or other possible future effects of present actions disappear.

In the following, I will zoom in on small moments at a strategy seminar where this familiar, linear strategy narrative collapses, leaving middle managers wondering about other possible future effects of their present efforts.

\section{The trail of a statement}

On the day of the seminar, I arrive early at the school together with an informant. The program of the day includes a short lecture by a professor in education from the regional university, followed by a set of questions that the middle managers are to discuss in smaller groups. Everything is ready in the assembly hall as we arrive: A PC, a projector, and a white screen for the professor's power point presentation, and circular tables with chairs around them. Soon, middle managers of different gender and age begin to fill the room, greet each other, chat a bit and eventually find seats. I - more or less randomly - 
chose three tables on which, after having asked for permission, I place digital recorders and then I find a seat at a fourth table.

\section{Scene 1: Dwelling in the familiar narrative}

After the presentation of the professor, the first question to be discussed around the tables appears on the large screen. It reads: 'Is it a problem if the teachers of a school do not share the same understanding of what good teaching is?' After a bit of 'well', 'yeah', and 'sometimes', the following exchange of words occurs at one table.

'It has something to do with history, going all the way back to the way in which teacher training colleges used to work. There you could not talk about what good teaching is because [in an ironic tone:] that can't be measured - it was not even a topic of discussion. Oh no. It is oh so subjective and contextual. [Normal voice:] It has something to do with how it has always been. It also has a lot to do with how strong the teacher union used to be.'

'I heard someone put it quite neatly: Everybody wants improvement, but no one wants change.'

'Yes, yes.'

'That's true.'

'It's completely true.'

'I would even say that the teacher culture nurtures hostility towards theory. They think external forces are evil and want to harm them. So they better shut the door to the classroom. It isn't easy to break with your own tradition and practice. Not when you're alone. When they work together in teams of two or three, I think it's easier.'

'And our culture and habits - the so-called freedom of methods - that is a dangerous phenomenon!'

The middle managers here confirm the familiar narrative provided to them by the corporate strategy. A specific genealogy of a problem of a lack of professional alignment is portrayed. The problem is depicted as having roots back to teacher training colleges, the former influence of the union and a general idea that teaching is a subjective rather than scientific question. We learn that the force of such habits is stronger when teachers are alone behind closed doors, and that it can be kept at a distance when teachers work together. The temporality of the organisation is ordered as a present in which struggles to improve and create a better future is obstructed by the 
obstinate habits of the past. When middle managers dwell in the familiar narrative, the problem of being a middle manager is that teachers are stubbornly holding on to outdated practices and habits and middle managers must struggle to create an improved future by disturbing and intervening in these practices and habits.

Also around other tables middle managers are eager to talk about how they work to transform the culture at their schools. They tell each other about the management concepts they apply and the consultancies they have hired to work with teachers' willingness to change. At one table, a middle manager says, 'If we want this change to become real we need to face the fact that we are the ones in charge of disturbing the teachers' 100 year old practices.' Another concurs: 'The big question we have to ask ourselves every day is how we create the sort of leadership, capable of reforming this culture.'

\section{Scene 2: Collapse of the familiar narrative}

This scene begins with yet a confirmation of the familiar narrative. However, thereafter the register suddenly changes.

\footnotetext{
'But it's this repetition of some unchangeable pre-understandings and rituals.'

'It's true. $80 \%$ of human beings are afraid of change.'

'But also considering what the presentation [by the professor] was actually also about, namely how our conditions of managing are shaped by the contemporary political climate and the direction our politicians want our education system to take. Actually, when I think about all the adverse consequences this will have for our children in the future, it sends a cold shiver down my spine.'
}

One middle manager reflects upon the broader development of the field of education. For a fleeting moment she looks into a different future. What she sees is not a future of a better performing, self-assessing organization to be achieved by intervening in old, obdurate habits. Rather, this middle manager seems to see another, gloomier future of not yet thought of darker consequences for children. This vision is accompanied by an embodied reaction, which she describes as a cold shiver down a spine. She seems to have heard the professor say something else, something more, that what she and her 
colleagues at first heard him say about the problem of a lack of alignment of teachers' practices and methods.

At first this disturbance of the familiar narrative does not change the conversation, which continues with several comments that apparently overhear or silently dismiss the statement. However, later, another manager returns to the same theme.

'Now that we talk about it. How many of us had imagined or thought about or realized how you can see the pupil plan [an assessment technology designed to evaluate the progress of the individual pupil] in this way? Did any of you ever consider that idea?

Did any of you ever feel it, or discovered it, or sensed it?'

This middle manager seems to suggest another way of looking at a particular assessment technique different from seeing it as a necessary tool to boost the performance of pupils. The narrative that ordered how this assessment technique could appear collapses in this very moment. He suggests transgressing a thinking about the pupil plan as something teachers are reluctant or even resistant to use and thereby as something middle managers need to work hard and think smart about how to implement. It is not clear from the conversation what he means by 'in this way' - how he now sees the pupil plan. However, he seems to be re-visioning it as part of a broader context different from the narrow and instrumental concern of implementation.

The middle manager is describing how at this specific moment in the conversation his feeling, sensing and thinking are radically altered. Something is not quite right anymore. He is somehow looking for other resources, registers, sensuous capabilities to make sense of things. In his wondering about why he had not seen the assessment technique as also having other effects, it seems to dawn on him that the strategy documents are telling one out of several possible tales about the future; that there are other futures at stake in the current efforts to improve. Neither of the two statements replace the familiar narrative with another coherent narrative - we do not learn much about what other futures they see. Far less about what future the middle managers would instead hope for. Rather, the two moments seem charged with unresolved tension. 
In these two particular moments, an uncanny atmosphere arises from the way in which a safe dwelling in a familiar setting and the use of a familiar narrative is all of a sudden not so safe and unproblematic anymore. In an unspecified manner the two middle managers begin to question the familiar narrative and wonder about its selfdescription as self-evident. Their concern is no longer strategy implementation and how to foster change as fast as possible, but an incipient wondering about the complexities at stake in the use of the familiar narrative. The question of which future middle managers shall work towards, which was settled by the familiar narrative, is all of a sudden not so settled anymore. These are uncanny moments in the sense that the fundamental propensity of the familiar narrative turns on its users and become defamiliarised, derealised, casting doubt on the familiar narrative (Vidler, 1999, p. 7). The middle managers begin to think about how the way of representing the organizational reality of the familiar strategy narrative may be more precarious than first assumed. They begin to sense that the familiar narrative might be an animate force in silencing certain concerns.

\section{Scene 3: Coming into contact with broader social and political stakes}

Again the conversation returns to familiar themes such as teachers' reluctance to share knowledge in a systematic fashion and management initiatives that might counter such reluctance. However, a bit later, the following exchange of words occurs:

\footnotetext{
'What kind of children will we get out of this? Just in ten years from now. How will children be children with the way in which the school has chosen to raise them, because that is what we do. We need to do all those things [top-management initiatives e.g. assessment procedures], but allowing ourselves to see how this effects children, what kind of adult life [pause] What kind of opinions and attitudes can they have. Because the way things are run [pause] It has consequences. Far out in the future.

'If we consider his [the professor] last point. What he is really saying is that if we do not produce the time to reflect, if we do not produce the time to interpret. Then other people will do it for us and is that good enough? We need to find out who it is, what it is and when is it that we, at our level of the organization begin to discuss these issues with each other.'

'And actively relate to what is going on.'
} 
'One needs to be attentive to the convenience that is lying there lurking just around the corner if one simply interprets one's role as an administrator, because then you find the good reasons to act outside yourself.'

'We need to relate to this. We need to become more active in our interpretation: What is it we want? Why do we want it? When do we want it? What matters to us?'

In this excerpt, the first middle manager sees a connection between the way the organization is currently being managed and a set of consequences 'far out in the future.' She and her colleagues envisions a horizon of consequences that none of them say out loud in any specified manner, but which several of them seem to see quite vividly. What they do say out loud is the question: 'What kind of children will we get out of this?' Again, a middle manager has heard the professor say something more than a lack of alignment of teachers' methods, namely a need for exactly these middle managers, sitting there listening and discussing, to more carefully think about and more actively relate to the current landscape of organizational change. One middle manager warns about how easy and convenient it can be to think of one self as a passive administrator of decisions coming from the outside. Finally, the last comment calls for more active interpretation and for the group of middle managers to think hard about what they themselves consider important and valuable. They call upon themselves not just to comply with normative expectations coming from the outside, but instead connect to reasons inside themselves. They call upon each other to work to create spaces in which such inner reasons can develop.

Recalling Gordon's (2011, p. 3) notion of a ghostly experience as a sociopolitical-psychological state when something else, or something different from before, feels like it must be done, it seems this group of middle managers have come into contact with something else than the familiar narrative and its expectations to them to secure the implementation of corporate strategies. They come into contact with the broader social and political stakes of their work and begin to long for some sort of counter action to the present development. They feel, in Gordon's terms, a somethingto-be-done, although the what, how and when of such action have yet to be thought of. The middle managers are somewhat undecided and request time to think and reflect 
rather than calling upon each other to act out direct resistance. The moment they are experiencing inspires neither immediate action nor a passive giving in. Rather, the middle managers are experiencing a sort of transformative recognition of the complex political forces also at stake in their current management practices.

\section{Strategy interruption on the edge of semantic availability}

Whereas existing literature has tended to describe disruptions to strategy implementation as deliberate resistance (Guth \& MacMillan, 1986; Meier, 2006), or related disruptions to difference in sensemaking between top and middle management (Balogun \& Johnson, 2004, 2005), this study has testified to a ghostly nature of interruptions. The kind of strategy interruption I have shown cannot be described as the arrival of one particular issue that so enrage or offend middle managers that resistance leaders emerge among them who carefully and skillfully organize and direct active counteractions (Courpasson et al., 2012; Zoller \& Fairhurst, 2007). Neither is it a form of interruption that can be explained as a difference in sensemaking between the top and the middle of an organisation due to geographical distance and cultural difference (Regnér, 2003; Mantere \& Vaara, 2008). Instead, what happens is an uncanny experience of beginning to question the organizational reality offered by corporate strategies. These middle managers are not just struggling to grasp strategies they did not design, socially negotiating the details, and thus making sense of the strategy in a way that differs from the strategic intentions in top management (Balogun \& Johnson, 2004, 2005). Rather, they are going through the uncanny experience of seeing before them the neat sequencing of past, present and future of a strategy narrative falling apart. The contingency and uncertainty controlled and silenced by corporate strategies re-surface and the middle managers begin to question the linear and causal reasoning of the strategy. They begin to wonder about the broader social and political consequences of their work.

What I have shown is a kind of interruption that entails less clear subject positions than suggested in studies of how middle managers step into a role as resistance leaders (Courpasson et al., 2012; Zoller \& Fairhurst, 2007), deliberately 
championing their own strategy alternatives (Dutton \& Ashford, 1993; Ketokivi \& Castañer, 2004). What happens is better described as a feeling of an urgent need for counteraction, where 'how' and 'when' remains to be known, and, meanwhile middle managers carry on with the business they were up to in the first place. The studied managers request time to think, reflect and connect to their own values rather than immediate action.

While some studies have shown how middle management entails ongoing movement between contradictory subject positions (Harding et al., 2014, Sims, 2003), such movement is often mapped and laid out through the model that frequently guides middle management studies, namely the double pressures from above and below organizational echelons. For example, the conclusion that Harding et al. (2014, p. 1232) offer is that:

'middle managers are controlled (object) by senior managers but must themselves practise control so are controllers (subjects). They resist the controls placed on them so are resisters (subject) but are resisted by staff so are resisted (object).'

In my study, what occurs is not simply a movement between subject positions of resister and resisted, controller and controlled. Rather, these middle managers encounter a staggering horizon of future possible adverse effects of present efforts. It is not only that these middle managers find it difficult to navigate between competing, identifiable demands, but also a much messier experience of coming into contact with concerns on the edge of what can be cognitively known from the present.

Similar to the work of Thomas and Linstead (2002), this study has related strategy interruption to how middle managers come to 'lose the plot' offered to them by corporate narratives. However, the focus of Thomas \& Linstead's study is how such experiences challenge middle managers in their struggle to secure an identity. Sims (2003, p. 1199) concurs that the feeling of losing the plot contributes to the experience of loneliness, precariousness and vulnerability of middle managers. In this study, however, the collapse of a familiar narrative does not only produce negative feelings, but also gives rise to a transformative recognition of the broader social and political stakes of middle managers' work to implement corporate strategies. What the experience of losing the plot produces is an embodied form of interruption and perhaps 
even resistance. In an everyday conversation designed to strengthen middle managers' capacity to implement a corporate strategy, an ethico-political reaction emerges to complex consequences far out in the future. Although, the middle managers of this study strike me as skilled and articulate individuals, what they experience seem almost at the edge of what they can put into words. The first comment to take up the concerns about adverse consequences of current strategies in the future describes a cold shiver down a spine and the second is looking for new sensuous registers to understand what is happening. We might describe this as a form of corporeal generosity (Pullen \& Rhodes, 2014) through which middle managers allow themselves, if only for a fleeting moment, to feel and express their concerns about the current strategy although they are not yet certain what to think about it, even less how to act. These middle managers are not resisting in the sense that they organize around a coherent alternative vision for their organization. However, in an embodied register they do feel a pressing concern and a need for other forms of actions. What I have called a ghostly experience is this form of resistance beyond rational self-interest, indeed on the edge of what middle managers can express in words and put into action. It is an embodied reaction, a something-to-bedone on the edge of semantic availability.

\section{Conclusion}

This study began with one statement and the intuition that it was lively, that is, capable of challenging the present and opening to different futures (Blackman, 2015). In a gentle, but arresting manner, the statement testified to the fact that at that moment, a not yet known future was making itself feel present. To explore the liveliness of the statement, I proposed an understanding of the ghostly as uncanny moments where the linearity of corporate strategies collapses and an excess of other possible orderings of time open up, allowing organizational actors to come into contact with the broader social and political stakes of their work.

In the first of three small empirical scenes, I have shown how the studied middle managers dwell safely in the familiar strategy narrative and its particular capturing of the organizational past, present and future. In the second scene, a shift of register occurs with the statement 'It sends a cold shiver down my spine' and the wonderings it sets in motion. All of a sudden, there is an openness to different forms of understanding the 
organizational reality and middle managers express the uncanny feeling that something more is at stake than seeing particular assessment techniques as simple means to better performance. The certain linear path towards a glossy future depicted by the corporate strategy collapses and middle managers glimpse into other, more gloomy futures. In the third scene, middle managers begin to request different forms of thinking and acting. They experience what Gordon has called a something-to-be-done, although the what, how and when of such action remain unclear.

A main contribution of the paper is theoretical and analytical understanding of interruptions to strategy implementation. While scholars have eloquently illuminated how strategy narratives often assume particular linear conceptions of organizational change resting on certain reductive ways of capturing and representing organizational realities (Chia \& Holt, 2009; Chia, 1999; Tsoukas \& Chia, 2002; Carter, Clegg, \& Kornberger, 2008), this study offers an understanding of the uncanny moments in which the edifice of corporate strategies fall apart. I have argued that strategy interruptions are moments in which what was before a well-known, familiar narrative is not so safe and self-evident anymore. Something is not quite right. Organizational actors begin to notice the forces at work to maintain the familiar strategy narrative as necessary and unproblematic.

The study contributes with novel understanding of the micro-dynamics through which, in spite of their general understanding of their role as implementation of corporate strategies (Reid, 1989), middle managers begin to reflect upon the broader social and political stakes of their work. Although interruption to strategy implementation sometimes do take the form of direct resistance (Dutton \& Ashford, 1993; Ketokivi \& Castañer, 2004), by emphasising its ghostly nature, this study has shown disruption, not to be a sort of epiphany where an individual all of a sudden knows exactly what to do, but an indeterminate, itchy awareness that something more is at stake. Although such moments are probably more common that direct, deliberate resistance, they remain largely absent in the literature, perhaps because they are fleeting and often too indeterminate to lend themselves to unambiguous analytical interpretation. The strategy interruption in this study brings more questions than answers. It is more like something waiting to happen than an actual event.

With the paper, I have sought to push what Orr (2014) has called an incipient 
spectral turn. Attempting to shake loose the rather disenchanted manners of operating of our discipline, recent papers in Organization Studies have called for stronger efforts to attune our scholarly apparatuses to the affective forces that haunt organizational life (Beyes \& Steyaert, 2013) and push our analytical curiosity towards shadows, darkness and enchantment (Linstead, Maréchal \& Griffin, 2014; Endrissat, Islam \& Noppeney, 2015). As O'Doherty, De Cock, Rehn and Ashcraft (2013, p. 1431) suggest what such efforts may generate is a new language of organizational time marked by the 'collapse of habitual temporal coordinates'. Indeed, the few available studies of the ghostly have unsettled the idea of organizational time as linear. With his organizational ghost stories, Orr (2014) discloses how inheritances of the past continue to haunt relations and struggles of the present. And Gabriel (2012) shows how fissures between new and old strategic agendas give rise to organizational existences of dubious ontology: people, values or habits that are doomed, but not yet departed.

What I add to this is an elaborated theoretical framework of the ghostly as the fleeting collapse of customary realities. Rather that assuming the ghostly to adhere to the well-known narrative of something lingering or returning from the past, I have described it as an animating excess of other possible orderings of time. What is thereby gained is appreciation, not only of how there is always more going on than what reaches customary accounts of organizational realities, but also of how ghostly moments may trigger a longing for other kinds of insights in the people they enchant: How they may push for a stretching towards the horizon of what cannot yet be seen with ordinary clarity (Gordon, 2008, p. 195).

Moreover, the paper adds to a potential spectral turn methodological and analytical attention to the vibrant agency of singular statements or moments. The paper has demonstrated what it means take seriously the liveliness of one statement and focus exclusively on the micro-drama spinning around it. This, I argue, makes it possible to direct attention to subtle forms of political actions occurring in embodied registers: A sort of corporeal generosity (Pullen \& Rhodes, 2014) through which organizational actors allow themselves, if only for a fleeting moment, to feel the violence and the hope inherent in their daily work, although they are not yet certain what to think, even less how to act.

Ultimately, the paper was meant to form part of current collective efforts to 
gnaw at the stubborn assumptions in our discipline e.g. about the linearity of organizational time or the causal effects of strategic efforts. Echoing Gabriel (2012) and Orr's (2014) insistence that the ghostly is not just another metaphor, my intention was not to add a little spice to the regular menu, but to make a meal out of the stuff normally left out of the feast: the uncanny forces of atmosphere concealed in everyday conversations, the liveliness of singular statements, thereby offering a theoretical framework that speaks to us about the reality of organization and organizing.

\section{References}

Alvesson, M. \& Sköldberg, K. (2000). Reflexive methodology: New vistas for qualitative research. London: Sage.

Benjamin, W. (1978). Surrealism. The last snapshot of the European intelligentsia. In P. Demetz (Ed.), Reflections: Essays, aphorisms, auto-biographical writings (pp. 177192). New York: Schocken Books.

Beyes, T., \& Steyaert, C. (2013). Strangely familiar: The uncanny and unsiting organizational analysis. Organization Studies, 34, 1445-1465.

Blackman, L. (2015). Researching Affect and Embodied Hauntologies: Exploring an Analytics of Experimentation. In Knudsen, B. \& Stage, C. (eds.) Affective Methodologies. Basingstoke: Palgrave.

Boje, D. (1991). The storytelling organization: A story of story performance in an office-supply firm. Administrative Science Quarterly, 36, 106-126.

Bower, J. L. (1970) Managing the resource allocation process, Harvard Business School. Boston. MA.

Carter, C., Clegg, S. R., \& Kornberger, M. (2008). Strategy as practice. Strategic organization, 6, 83-99.

Chia, R. (1999). A 'rhizomic'model of organizational change and transformation: perspective from a metaphysics of change. British journal of management, 10, 209-227. Chia, R. C., \& Holt, R. (2009). Strategy without design: The silent efficacy of indirect action. Cambridge University Press. 
Chia, R., \& MacKay, B. (2007). Post-processual challenges for the emerging strategyas-practice perspective: Discovering strategy in the logic of practice. Human relations, 60, 217-242.

Cho, G. M. (2008). Haunting the Korean Diaspora: Shame, Secrecy and the Forgotten War. Minneapolis, MN: University of Minnesota Press.

Clegg, S., Carter, C., \& Kornberger, M. (2004). Get up, I feel like being a strategy machine. European Management Review, 1, 21-28.

Coddington, K. S. (2011). Spectral geographies: haunting and everyday state practices in colonial and present-day Alaska. Social \& Cultural Geography, 12, 743-756.

Courpasson, D., Dany, F., \& Clegg, S. (2012). Resisters at work: Generating productive resistance in the workplace. Organization Science, 23, 801-819.

Czarniawska, B. (2008). Organizing: how to study it and how to write about it. Qualitative Research in Organizations and Management: An International Journal, 3, 4-20.

Czarniawska, B. (2007). Shadowing and other techniques for doing fieldwork in modern societies. Malmo: Liber.

Danish Institute of Evaluation (2006). Skoleledelse i folkeskolen. [Management in the school] Copenhagen: Danish Institute of Evaluation.

Danish Ministry of Education (2007). Improving School Leadership - En national baggrundsrapport. [Improving school Leadership - a national report] Conducted by Pluss Leadership A/S. Copenhagen: Ministry of Education.

De Certeau, M. (1984). The Practice of Everyday Life. Berkeley: University of California Press.

De Cock, C., O’Doherty, D. \& Rehn, A. (2013). Specters, ruins and chimeras:

Management \& Organizational History's encounter with Benjamin. Management \& Organizational History, 8, 1-9.

Degen, M. \& Hetherington, K. (2001). Guest editorial: hauntings. Space and Culture $11 / 12,1-6$. 
Dutton, J. E., \& Ashford, S. J. (1993). Selling issues to top management. Academy of management review, 18, 397-428.

Edensor, T. (2001). Haunting in the ruins: matter and immateriality. Space and Culture, $11 / 12,42-51$.

Edensor, T. (2008). Mundane hauntings: Commuting through the phantasmagoric working-class spaces of Manchester, England. Cultural Geographies, 15, 313-333.

Endrissat, N., Islam, G., \& Noppeney, C. (2015). Enchanting work: New spirits of service work in an organic supermarket. Organization Studies, 36, 1555-1576.

Floyd, S. \& Wooldridge, B. (1992) Middle management involvement in strategy and its association with strategic type: A research note. Strategic Management Journal, 13, $153-167$.

Freud, S. (2003). The uncanny. In S. Freud, The Uncanny. London: Penguin books.

Gabriel, Y. (2012). Organizations in a state of darkness: Towards a theory of organizational miasma. Organization Studies, 33, 1137-1152.

Gandy, M. (1999). The Paris sewers and the rationalization of urban space.

Transactions of the Institute of British Geographers, 24, 23-44.

Gordon, A. (2011). Some thoughts on haunting and futurity. Borderlands, 10(2), 1-21.

Gordon, A. F. (2008). Ghostly matters: Haunting and the sociological imagination. Minneapolis: University of Minnesota Press.

Guth, W. D., \& MacMillan, I. C. (1986). Strategy implementation versus middle management self-interest. Strategic Management Journal, 7, 313-327.

Harding, N., Lee, H. \& Ford, J. (2014). Who is 'the middle manager'? Human Relations, 67(10), 1213-1237.

Hetherington, K. (2004). Secondhandedness: consumption, disposal and absent presence. Environment and planning d: society and space 22, 157-73.

Holloway, J., \& Kneale, J. (2008). Locating haunting: a ghost-hunter's guide. cultural geographies, 15, 297-312. 
Hrebiniak, L. G. \& Joyce, W. F. (1984). Implementing strategy. New York, NY: Macmillan.

Jameson, F. (1999). Marx's Purloined Letter. In Sprinker, M. (ed.), Ghostly

Demarcations. A symposium on Jacques Derrida's Spectres of Marx. London: Verso.

Johnson, L. W., \& Frohman, A. L. (1989). Identifying and closing the gap in the middle of organizations. The Academy of Management Executive, 3, 107-114.

Ketokivi, M., \& Castañer, X. (2004). Strategic planning as an integrative device.

Administrative Science Quarterly, 49, 337-365.

Kociatkiewicz, J., \& Kostera, M. (1999). The anthropology of empty spaces.

Qualitative Sociology, 22, 37-50.

Linstead, S., Maréchal, G., \& Griffin, R. W. (2014). Theorizing and researching the dark side of organization. Organization Studies, 35, 165-188.

Linstead, A. \& Thomas, R. (2002). "What Do You Want from Me?" A Poststructuralist Feminist Reading of Middle Managers' Identities. Culture and organization, 8, 1-20.

LGDK (2005). Evalueringskultur. En ny skoletradition. [A culture of evaluation. A new school tradition] Copenhagen: LGDK.

LGDK (2008a) Kommunerne styrer mod god kvalitet og høj faglighed $i$

folkeskolen.[Governing high quality and educational standards] Copenhagen: LGDK.

LGDK (2009). Kvalitet i kommunerne - resultater fra kvalitetsprojektet. [Quality in the municipalities - results from a quality project]. Copenhagen: LGDK.

LGDK (2010a) Alle elever skal have stфrre udbytte af undervisningen [All pupils must gain more from teaching] $22^{\text {nd }}$ of January 2010. Copenhagen: LGDK.

LGDK (2010b). Folkeskolen - Et stort kommunalpolitisk ansvar. [The public school - a great responsibility of local politics]. News from the board of $L G D K$, Special Issue, January 2010 .

Luckhurst, R. (2013). From The contemporary London gothic and the limiets of the “spectral turn.” In Blanco, M. \& Peeren, E. (eds.), The spectralities reader. Ghost and haunting in contemporary cultural theory. London: Bloomsbury Academic. 
Maddern, J.F. (2008). Spectres of migration and the ghosts of Ellis Island. Cultural Geographies, 15, 359- 381.

Mantere, S. (2013). What Is Organizational Strategy? A Language-Based View. Journal of Management Studies, 50, 1408-1426.

Mantere, S., \& Vaara, E. (2008). On the problem of participation in strategy: A critical discursive perspective. Organization Science, 19, 341-358.

McCabe, D. (2011) Opening Pandora's box: The unintended consequences of Stephen Covey's effectiveness movement. Management Learning 42, 183-197.

McCormack, D. P. (2010). Remotely sensing affective afterlives: The spectral geographies of material remains. Annals of the Association of American Geographers, $100,640-654$.

Meyer, C. B. (2006). Destructive dynamics of middle management intervention in postmerger processes. Journal of Applied Behavioral Science, 42, 397-419.

Muhr, S. L \& Azad, S. (2013). Specters of Colonialism: Illusionary Equality and the Forgetting of History in a Swedish Organization. Management \& Organizational History, 8, 62-76.

Nonaka, W. D., \& MacMillan, I. C. (1986). Strategy implementation versus middle management self-interest. Strategic Management Journal, 7, 313-327.

Nutt, P. C. (1987). Identifying and appraising how managers install strategy. Strategic Management Journal, 8, 1-14.

O’Doherty, D., De Cock, C., Rehn, A., \& Ashcraft, K. L. (2013). New sites/sights: Exploring the white spaces of organization. Organization Studies, 34, 1427-1444.

OECD (2004). OECD-rapport om grundskolen i Danmark - 2004. [OECD-report on the primary school in Denmark] Conducted by Mortimore, P., David-Evans, M., Laukkanen, R., Valijarvi, J. The Agency of Education theme series no. 5.

Orr, K. (2014). Local government chief executives' everyday hauntings: Towards a theory of organizational ghosts. Organization Studies, 35, 1041-1061. 
Pile, S. (2005). Real cities: Modernity, space and the phantasmagorias of city life. London: Sage.

Pullen, A., \& Rhodes, C. (2014). Corporeal ethics and the politics of resistance in organizations. Organization, 21, 782-796.

Raes, A. M., Heijltjes, M. G., Glunk, U., \& Roe, R. A. (2011). The interface of the top management team and middle managers: A process model. Academy of Management Review, 36, 102-126.

Regnér, P. (2003). Strategy creation in the periphery: Inductive versus deductive strategy making. Journal of Management Studies, 40, 57-82.

Reid, D. M. (1989). Operationalizing strategic planning. Strategic Management Journal, 10, 553-567.

Sims, D. (2003). Between the millstones: A narrative account of the vulnerability of middle managers' storying. Human Relations, 56, 1195-1211.

Symon, G., \& Cassell, C.M. (2012). Assessing qualitative research. In G. Symon \& C. M. Cassell (Eds.), Qualitative organizational research: Core methods and current challenges (pp. 204-223). London: SAGE Publications.

Till, K. (2005). The new Berlin. Minneapolis: University of Minnesota Press.

Thomas, R., \& Linstead, A. (2002). Losing the plot? Middle managers and identity. Organization, 9, 71-93.

Tsoukas, H., \& Chia, R. (2002). On organizational becoming: Rethinking organizational change. Organization Science, 13, 567-582.

Vidler, A. (1999). The architectural uncanny: essays in the modern unhomely. Cambridge, MA: MIT Press.

Ybema, S., Yanow, D., Wels, H., \& Kamsteeg, F. H. (Eds.) (2009). Organizational ethnography: Studying the complexity of everyday life. Sage. 
Zoller, H. M., \& Fairhurst, G. T. (2007). Resistance leadership: The overlooked potential in critical organization and leadership studies. Human Relations, 60, 13311360.

Warren, S. (2008). Empirical Challenges in Organizational Aesthetics Research:

Towards a Sensual Methodology. Organization Studies, 29, 559-580.

${ }^{1}$ The literal translation of the German notion of the uncanny, 'das Unheimliche', is unhomely. 